\title{
Source Rock Evaluation in The Lake Chad Area of the Bornu Basin, Nigeria
}

\author{
Ola Peter Sunday ${ }^{1}$, Adekoya John Adeyinka ${ }^{2}$ and Olabode Solomon Ojo ${ }^{1}$
}

${ }^{1}$ Department of Applied Geology, Federal University of Technology, Akure, Nigeria

${ }^{2}$ Department of Geological Sciences, Osun State University, Osogbo, Nigeria

\begin{abstract}
Source rock evaluation of the Lake Chad area of the Bornu Basin which contains a comparatively thicker sedimentary succession based on interpreted seismic and gravity data was undertaken in this study. A total of twenty-nine shale samples from three wells (Kutchali-1, Faltu-1 and Herwa-1) were analysed to arrive at the bulk geochemical properties, organic matter particles and vitrinite reflectance (VR) data of the strata penetrated by the wells. The Lake Chad area appears to contain the main ingredients required to make a rich source rock with over $96 \%$ of the total organic carbon (TOC) values being in the range of $0.63-2.88 \mathrm{wt} \%$ and over $95 \%$ having $\mathrm{T}_{\max }$ greater than $435^{\circ} \mathrm{C}$ in most of the sampled intervals. The variation of Tmax and VR with depth in the wells reveals irregular decreases or subtle decreasing trends that are suggestive of cooling in the basin's thermal history probably as a result of uplift and erosion. The uplift could have been caused by epeirogenic movement or by folding related to the Santonian inversion witnessed by the West African Rift Subsystem. In terms of hydrocarbon generation potential, most of the samples have $\mathrm{HI}$ values greater than $50 \mathrm{mgHC} / \mathrm{g}$ TOC, but generally less than $200 \mathrm{mgHC} / \mathrm{g}$ TOC. These $\mathrm{HI}$ values suggest dominance of Type III with less Type II Kerogen; thus, a predominantly predominantly gas prone area. A study of some bulk geochemical parameters (TOC, $\mathrm{T}_{\mathrm{max}}$ and $\mathrm{HI}$ ) of the three study wells has revealed that the succession penetrated by one of them (Faltu- 1 well) contains several potential gas source intervals and two potential oil source intervals with the latter probably lying between $2500 \mathrm{~m}$ and $3000 \mathrm{~m}$ depth.
\end{abstract}

Keywords: Source rock; Bornu Basin; Kutchali; Bulk geochemistry; Fika Shale

\section{Introduction}

Following the discovery of oil in parts of the mega-Chad Basin that fall within the neighbouring countries of Chad and Niger Republics (i.e the Termit Basin) in the seventies, the Nigerian National Petroleum Corporation, a parastatal of the Federal Government of Nigeria, was encouraged to carry out oil exploration in Bornu Basin which is the Nigerian sector of the mega-Chad Basin. The mega-Chad Basin covers all the rift basins associated with the West and Central African Rift System (WCARS) [1] which lie within the confine of the ancient inland Chad Basin. The exploration involved acquisition of 33,642 km of 2-D seismic lines and sinking 23 wells which provided subsurface materials for detailed studies including source rock evaluation. Unfortunately, the exploration campaign was unsuccessful as only uneconomic gas find was reported.

Recently there is renewed interest by the Federal Government to revisit the basin. This calls for re-evaluation of the prospectively of the different areas of the basin. Evaluation of potential source rock is an important parameter to be considered in reviewing and isolating the most auspicious area for further work. Previous workers, notably, Olugbemiro, Obaje, Moumouni and Alalade and Tyson [2-5] have evaluated potential source rocks in some parts of the basin, although the selection of materials for the analysis appears haphazard. These works have been reviewed in Adekoya [6] suggesting that the basin contain sufficient hydrocarbon generation elements. In the present study, source rock evaluation is focused on the north-eastern portion of the Bornu Basin where a thick sedimentary cover, possibly the thickest in the basin, is speculated on the basis of magnetic and gravity data interpretation and well $\log$ information [7,8]. Borehole cuttings were selected from three wells-Kutchali-1, Herwa-1 and Faltu-1-in the area for organic geochemical studies. The purpose is to shed more light on source rock availability in that part of the basin believed to have high prospective potential for hydrocarbon discovery, more so that the area is very close to the oil-producing Termit Basin of Chad and Niger Republics.

\section{Geological setting}

The geological setting of the Bornu Basin is similar, to a large extent to other rift basins in the West and Central African Rift systems (WCARS) that are petroleum producing. They were all either a product of strike-slip or extensional forces that brought about the mechanical separation of African and South American crustal blocks during the Early Cretaceous [9-11]. The study of the geology of the Bornu Basin has received considerable attention mainly because of its presumed hydrocarbon potential, ground water exploration and its position in relation to the connection of the Tethys Sea with the Atlantic Ocean during the Cretaceous [12-20].

\section{Stratigraphy}

The Precambrian Basement Complex constitutes the bedrock on which sediments ranging in age from Mesozoic to the Quaternary have been deposited in the Bornu Basin, which is one of the rift basins associated with the WCARS [1]. The sedimentary fill of the basin is divided into six defined lithostratigraphic units and two unnamed units (Figure 1). The oldest named unit, the Bima Formation, consists of sparsely fossiliferous, poorly sorted, cross-stratified, fine- to coarsegrained arkosic sandstones interlayered with clay/shale, which are interpreted as fluvial and lacustrine deposits $[17,21]$. These continental

Corresponding author: Ola PS, Department of Applied Geology, Federal University of Technology, Akure, Nigeria, Tel: 08060981972; E-mail: psola@futa.edu.ng

Received June 21, 2017; Accepted October 26, 2017; Published October 31 2017

Citation: Ola PS, Adekoya JA, Olabode SO (2017) Source Rock Evaluation in The Lake Chad Area of the Bornu Basin, Nigeria. J Pet Environ Biotechnol 8: 346. doi: $10.4172 / 2157-7463.1000346$

Copyright: (C) 2017 Ola PS, et al. This is an open-access article distributed under the terms of the Creative Commons Attribution License, which permits unrestricted use, distribution, and reproduction in any medium, provided the original author and source are credited. 
Citation: Ola PS, Adekoya JA, Olabode SO (2017) Source Rock Evaluation in The Lake Chad Area of the Bornu Basin, Nigeria. J Pet Environ Biotechnol 8: 346. doi: 10.4172/2157-7463.1000346

Page 2 of 9

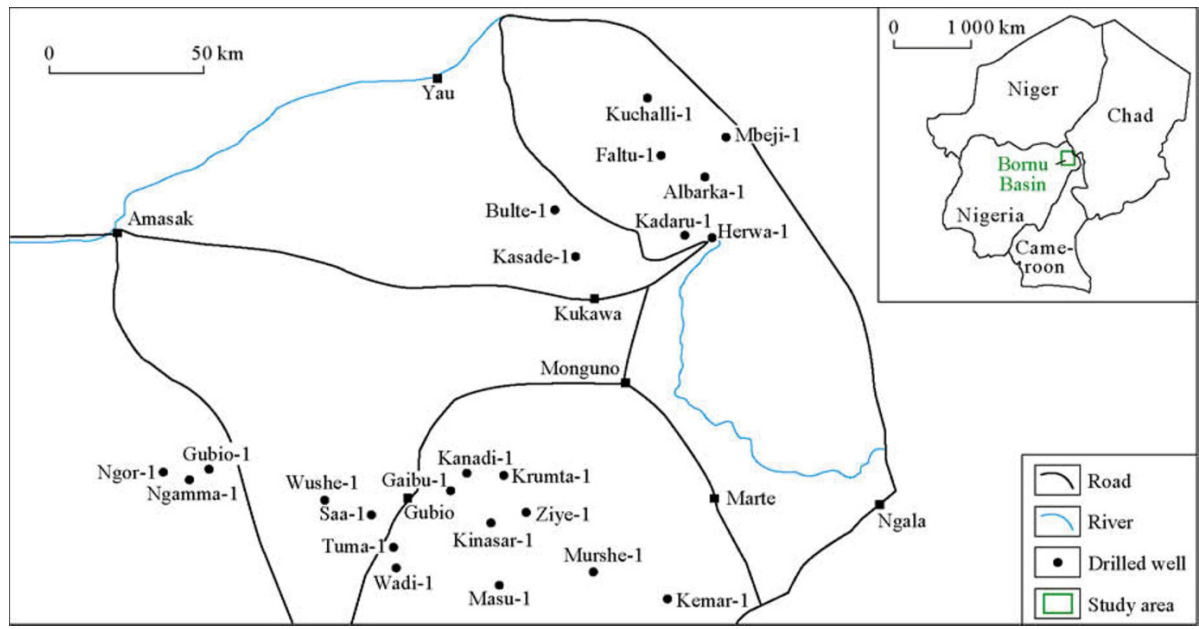

Figure 1: Map of the Bornu Basin showing the location of drilled wells in the basin and three areas of thick sedimentary deposits in the basin marked as depression $\mathrm{A}$ $B$ and C (Modified after Olabode [7]). The focus of this study is on depression A occurring in the area around the Lake Chad.

\begin{tabular}{|c|c|c|c|c|c|c|c|}
\hline System & Series & Stage & Formation & Lithology & $\begin{array}{c}\text { Average } \\
\text { thickness } / \mathrm{m}\end{array}$ & $\begin{array}{l}\text { Thickness from } \\
\text { seismic data/m }\end{array}$ & Outcrop Description \\
\hline $\begin{array}{l}\text { Quater- } \\
\text { nary }\end{array}$ & & & Chad & 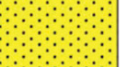 & 400 & \multirow{2}{*}{$\begin{array}{c}800 \\
\text { (Average) }\end{array}$} & $\begin{array}{l}\text { Variegated clays with } \\
\text { sand interbeds }\end{array}$ \\
\hline Tertiary & & & Kerri-Keni & @ & 130 & & $\begin{array}{l}\text { Iron rich sandstone and clay } \\
\text { covered by plinth of laterite }\end{array}$ \\
\hline \multirow{6}{*}{ 宽 } & \multirow{4}{*}{ Upper } & Maastrichtian & Gombe & $\vdots$ & 315 & $0-1000$ & $\begin{array}{l}\text { Sandstone, siltstone and } \\
\text { clay with coal beds. Fossils, } \\
\text { bivalve impressions and } \\
\text { Cruziana lebana purren }\end{array}$ \\
\hline & & Senonian & Fika & & 430 & $0-900$ & $\begin{array}{l}\text { Shale, dark gray to black, } \\
\text { gypsiferous with limestone beds }\end{array}$ \\
\hline & & Turonian & Gongila & $\because \because \because \because \because \because \because \because$ & 420 & $0-800$ & $\begin{array}{l}\text { Alternating sandstone and } \\
\text { shale with limestone beds }\end{array}$ \\
\hline & & Cenomanian & Bima & $\because \bigcirc \bigcirc \bigcirc \bigcirc \square$ & 3050 & 2000 & $\begin{array}{l}\text { Sandstone, gravelly to } \\
\text { medium grained, poorly sorted } \\
\text { and highly feldspathic }\end{array}$ \\
\hline & \multirow{2}{*}{ Lower } & \multirow{2}{*}{ Albian } & Unnamed & 崖??? & & 3600 & $\begin{array}{l}\text { Seismically transparent sequence, } \\
\text { monolithologic sequence inferred }\end{array}$ \\
\hline & & & Unnamed & $\because$ & & $0-3000$ & $\begin{array}{l}\text { Piedmont alluvial fans } \\
\text { early rift sediments }\end{array}$ \\
\hline $\begin{array}{c}\text { Pre- } \\
\text { cambrian }\end{array}$ & & & Basement & 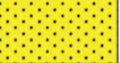 & & & \\
\hline
\end{tabular}

Figure 2: Stratigraphic Units in the Bornu Basin $[17,25]$.

sediments were deposited directly on the seismically defined two unnamed units (also observed in outcrop, Avbovbo [17] that were likely deposited during the Aptian-Albian early rift stage or rift phase I of Genik [1,20] or syn-rift phase I of Popoff [22]. Regional extensional events during the Cenomanian marked the onset of marine transgression in the basin $[2,17,20]$, which some authors claimed to have led to the deposition of Yolde Formation. A short-lived regressive phase of the transgression period led to the deposition of the Gongila Formation. Sediments of this formation consist of basal limestone and overlying sandstone-shale alternating sequence. Some authors prefer to merge the two formations (Yobe and Gongila) together as the Gongila Formation (Figure 2) Marine transgression predominated throughout most of the Turonian and reached its peak in the late Turonian to Senonian, when sediments of Fika Formation were deposited in an open marine environment $[3,4,23]$. This formation conformably rests on the Gongila Formation and consists of blue to black, thick-bedded shales, which sometimes contain gypsum, and thin interbedded siltstones and sandstones. According to Alalade [8] the upper part of Fika Formation was deposited under an oceanic anoxic event. Following the Santonian Squeeze event recorded in the basins of WCARS, there was an uplift 
and erosion in the basin. This event was followed by the deposition of Gombe Formation lying unconformably on the Fika Formation. Gombe Formation consists of alternating siltstones, clays, and sandstones that become ferruginous towards the top. This formation is interpreted to have been deposited in an estuarine to deltaic environment during the Maastrichtian $[4,17]$. The last rifting phase in the Chad Basin during the late Maastrichtian to Paleocene resulted in development of a series of NE-SW horst and graben structures. This phase was followed by a long period of non-deposition $[4,20]$. The long unconformity period elapsed with the deposition of Kerri-Kerri Formation, probably in a continental (lacustrine) environment during the Neogene. The KerriKerri Formation consists of loose coarse- to fine-grained, cross-bedded shaly sandstones. The youngest formation, Chad Formation, also of continental origin, comprise fine- to coarse-grained sandstones with intercalated sandy clay, clay and diatomite deposited during the Pliocene. The central and southern parts of the Chad Basin experienced widespread of volcanic activities in the late Tertiary to recent [24].

\section{Methodology}

A total of 29 samples were carefully selected from three wellsKuchali-1; Herwa-1 and Faltu-1 located in the Lake Chad area of the Bornu Basin for this study [25]. One major factor that guided the sample selection was detailed visual sedimentologic studies of all the cuttings of the wells to eliminate samples with poor organic matter content i.e. sands, marl and clay. The selected samples were assigned to different formations based on the interpretation carried out by Olabode [7] using the lithological characteristics derived from the well logs.

The samples were sieve-washed under running water to remove drilling contaminants, dried and pulverized. One gram of powdered sample was decarbonated with $\mathrm{HCl}$ and utilized for total organic carbon (TOC) analyses using a LECO-CS 244 carbon analyser.
After the TOC analysis, the Rock-Eval pyrolysis was performed on the samples utilizing $100 \mathrm{mg}$ of powdered borehole cuttings and was done using a GEO-IMT-2005 instrument. Ground sediment samples were heated in an inert atmosphere at $300^{\circ} \mathrm{C}$ to liberate hydrocarbons which have been generated but not expelled from the source rock (S1). Further heating to $650^{\circ} \mathrm{C}$ led to the generation of all further potential hydrocarbons from the sample (S2). The temperature at the peak of S2 marks the Tmax. The quantity of hydrocarbons was measured by using an external standard method, built into the Rock-Eval data system. A response curve for the instrument's FID detector was calibrated in mg (oil)/gram (rock) using known IFP standards. The hydrogen index (HI) was determined as the yield of reduced products of pyrolysis (S2) relative to the TOC (mg HC/g TOC) while the oxygen index (OI), which is the yield of the oxygen and bound organic carbon (S3) deduced from the relation $\mathrm{S} 3 /(\mathrm{S} 1+\mathrm{S} 2)$.

\section{Result}

\section{Bulk geochemistry}

Twenty-nine samples from three wells (Kutchali-1 (7), Faltu-1 (11), and Herwa-1(11)) were analysed to arrive at the bulk geochemical properties of the strata penetrated by the wells (Tables 1 and 2). Since evaluation of a rock has to be based on integration of multiple parameters to ascertain availability of source rock in a basin the plot of TOC, $\mathrm{HI}$ and $\mathrm{T}_{\max }$ against depth for each of the three wells was made (Figures 3-5).

\section{Organic particles and vitrinite reflectance value}

The organic particles contained in selected samples and their corresponding vitrinite reflectance data obtained for Kutchali -1, Faltu -1 and Herwa-1 are displayed in Figures 6-8 respectively.

Kutchali-1: Only three samples picked at depths of 1890 m, 2190 m

\begin{tabular}{|c|c|c|c|c|c|c|c|c|c|c|c|c|c|}
\hline Age & $\begin{array}{c}\text { Formation } \\
\text { (Olabode et al.) }\end{array}$ & Lithology & $\begin{array}{l}\text { Depth } \\
\text { (m) }\end{array}$ & TOC (wt.\%) & $\begin{array}{c}\mathrm{S} 1 \\
\mathrm{mg} / \mathrm{g}\end{array}$ & $\begin{array}{c}\mathrm{S} 2 \\
\mathrm{mg} / \mathrm{g}\end{array}$ & $\begin{array}{c}\mathrm{S} 3 \\
\mathrm{mg} / \mathrm{g}\end{array}$ & $\begin{array}{c}\mathrm{HI}=\mathrm{S} 2 / \mathrm{TOC} \\
\times 100\end{array}$ & $\begin{array}{c}\mathrm{OI}=\mathrm{S} 3 \mathrm{I} \\
(\mathrm{S} 1+\mathrm{S} 2)\end{array}$ & $\begin{array}{c}\mathrm{PI}=\mathrm{S} 1 / \\
(\mathrm{S} 1+\mathrm{S} 2)\end{array}$ & Tmax & S2/S3 & $\begin{array}{c}\text { S1/TOC } \times \\
100\end{array}$ \\
\hline \multicolumn{14}{|c|}{ Herwa-1 } \\
\hline $\begin{array}{l}\text { U. Santonian } \\
\text {-Campanian }\end{array}$ & \multirow{8}{*}{ Fika } & Shale & 2000 & 0.63 & 0.19 & 0.59 & 0.83 & 94 & 132 & 0.24 & 432 & 0.71 & 30.16 \\
\hline $\begin{array}{l}\text { U. Santonian- } \\
\text { Campanian }\end{array}$ & & Shale & 2250 & 1.1 & 0.32 & 1.37 & 1.09 & 125 & 99 & 0.19 & 436 & 1.26 & 29.09 \\
\hline $\begin{array}{l}\text { Santonian-L. } \\
\text { Campanian }\end{array}$ & & Shale & 2350 & 0.8 & 0.14 & 0.79 & 1.37 & 99 & 171 & 0.15 & 436 & 0.58 & 17.5 \\
\hline $\begin{array}{l}\text { Santonian-L. } \\
\text { Campanian }\end{array}$ & & Shale & 2550 & 0.82 & 0.3 & 1.01 & 1.12 & 123 & 137 & 0.23 & 441 & 0.9 & 36.59 \\
\hline Coniacian & & Shale & 2700 & 0.76 & 0.17 & 0.88 & 1.09 & 116 & 143 & 0.16 & 427 & 0.81 & 22.37 \\
\hline Coniacian & & Shale & 2850 & 0.72 & 0.23 & 0.81 & 0.98 & 113 & 136 & 0.22 & 437 & 0.83 & 31.94 \\
\hline Coniacian & & Shale & 3250 & 0.18 & & & & & & & & & \\
\hline Coniacian & & Shale & 3400 & 0.66 & 0.2 & 0.37 & 0.65 & 56 & 98 & 0.35 & 380 & 0.57 & 30.3 \\
\hline $\begin{array}{l}\text { Cenomanian } \\
\text {-Turonian }\end{array}$ & Yolde/Gongila & Shale & 4000 & 0.74 & 0.23 & 0.91 & 0.71 & 123 & 96 & 0.2 & 439 & 1.28 & 31.08 \\
\hline $\begin{array}{l}\text { Albian and } \\
\text { Older }\end{array}$ & \multirow{2}{*}{ Bima } & Shale & 4200 & 0.63 & 0.2 & 0.78 & 0.87 & 124 & 138 & 0.2 & 443 & 0.9 & 31.75 \\
\hline $\begin{array}{l}\text { Albian and } \\
\text { Older }\end{array}$ & & Shale & 4550 & 1.1 & 0.35 & 0.82 & 1.24 & 75 & 113 & 0.31 & 384 & 0.66 & 31.82 \\
\hline \multicolumn{14}{|c|}{ Faltu-1 } \\
\hline $\begin{array}{l}\text { Santonian-L. } \\
\text { Campanian }\end{array}$ & \multirow{5}{*}{ Fika } & Shale & 1560 & 0.78 & 0.07 & 0.3 & 0.88 & 38 & 112 & 0.19 & 429 & 0.3 & 8.94 \\
\hline $\begin{array}{l}\text { Santonian-L. } \\
\text { Campanian }\end{array}$ & & Shale & 1700 & 0.68 & 0.05 & 0.26 & 0.66 & 38 & 97 & 0.16 & 434 & 0.4 & 7.33 \\
\hline Coniacian & & Shale & 1940 & 0.76 & 0.04 & 0.11 & 0.61 & 14 & 80 & 0.27 & 431 & 0.2 & 4.18 \\
\hline Coniacian & & Shale & 2140 & 0.64 & 0.05 & 0.26 & 0.52 & 41 & 82 & 0.16 & 431 & 0.5 & 5.24 \\
\hline Coniacian & & Shale & 2220 & 0.93 & 0.07 & 0.84 & 0.47 & 90 & 51 & 0.08 & 435 & 1.8 & 7.84 \\
\hline Turonian & Gongila & Shale & 2340 & 0.86 & 0.05 & 0.71 & 0.49 & 83 & 57 & 0.07 & 434 & 1.4 & 6.9 \\
\hline
\end{tabular}


Citation: Ola PS, Adekoya JA, Olabode SO (2017) Source Rock Evaluation in The Lake Chad Area of the Bornu Basin, Nigeria. J Pet Environ Biotechnol 8: 346. doi: 10.4172/2157-7463.1000346

Page 4 of 9

\begin{tabular}{|c|c|c|c|c|c|c|c|c|c|c|c|c|c|}
\hline $\begin{array}{c}\text { Cenomanian-L. } \\
\text { Turonian }\end{array}$ & \multirow{5}{*}{ Yolde } & Shale & 2420 & 1.18 & 0.04 & 0.46 & 0.69 & 39 & 58 & 0.08 & 428 & 0.7 & 7.85 \\
\hline Albian & & Shale & 2460 & 0.65 & 0.06 & 1.05 & 0.38 & 162 & 59 & 0.05 & 439 & 2.8 & 7.53 \\
\hline $\begin{array}{l}\text { Albian and } \\
\text { Older }\end{array}$ & & Shale & 2560 & 1.62 & 0.09 & 4.53 & 0.46 & 280 & 28 & 0.02 & 445 & 9.8 & 5.79 \\
\hline $\begin{array}{l}\text { Albian and } \\
\text { Older }\end{array}$ & & Shale & 2920 & 2.88 & 0.3 & 7.38 & 0.7 & 256 & 24 & 0.04 & 443 & 10.5 & 5.84 \\
\hline $\begin{array}{l}\text { Albian and } \\
\text { Older }\end{array}$ & & Shale & 3120 & 0.8 & 0.1 & 0.68 & 0.62 & 86 & 78 & 0.13 & 441 & 1.1 & 13.75 \\
\hline \multicolumn{14}{|c|}{ Kutchali-1 } \\
\hline $\begin{array}{l}\text { Santonian-L. } \\
\text { Campanian }\end{array}$ & \multirow{6}{*}{ Fika } & Shale & 1890 & 0.92 & 0.12 & 0.56 & 0.38 & 61 & 41 & 0.18 & 432 & 1.47 & 13.04 \\
\hline $\begin{array}{l}\text { Santonian-L. } \\
\text { Campanian }\end{array}$ & & Shale & 1950 & 1.09 & 0.28 & 0.98 & 0.44 & 90 & 40 & 0.22 & 432 & 2.23 & 25.69 \\
\hline $\begin{array}{l}\text { Santonian-L. } \\
\text { Campanian }\end{array}$ & & Shale & 2070 & 0.77 & 0.14 & 0.6 & 0.33 & 78 & 43 & 0.19 & 438 & 1.82 & 18.18 \\
\hline U. Coniacian & & Shale & 2190 & 0.92 & 0.22 & 0.82 & 0.5 & 89 & 54 & 0.21 & 441 & 1.64 & 23.91 \\
\hline U. Coniacian & & Shale & 2220 & 0.72 & 0.12 & 0.61 & 0.39 & 85 & 54 & 0.16 & 440 & 1.56 & 16.67 \\
\hline U. Coniacian & & Shale & 2280 & 0.8 & 0.09 & 0.56 & 0.3 & 70 & 38 & 0.14 & 439 & 1.87 & 11.25 \\
\hline Turonian & Gongila & Shale & 2790 & 0.83 & 0.43 & 1.31 & 2.31 & 158 & 278 & 0.25 & 421 & 0.57 & 51.81 \\
\hline
\end{tabular}

Table 1: TOC and Rock-Eval pyrolysis data for three wells in the Nigerian sector of Chad Basin.

\begin{tabular}{|c|c|c|c|c|}
\hline Depth (m) & Vitrinite reflectance (\%Ro) & Standard deviation & Count & Confidence (95\%) \\
\hline 1890 & 0.60 & 0.04 & 3 & 0.10 \\
\hline 2190 & 0.80 & 0.06 & 6 & 0.06 \\
\hline 2790 & 0.88 & 0.05 & 6 & 0.05 \\
\hline
\end{tabular}

Table 2: Vitrinite reflectance data to determine source rock status of some strata penetrated by Faltu-1 well.

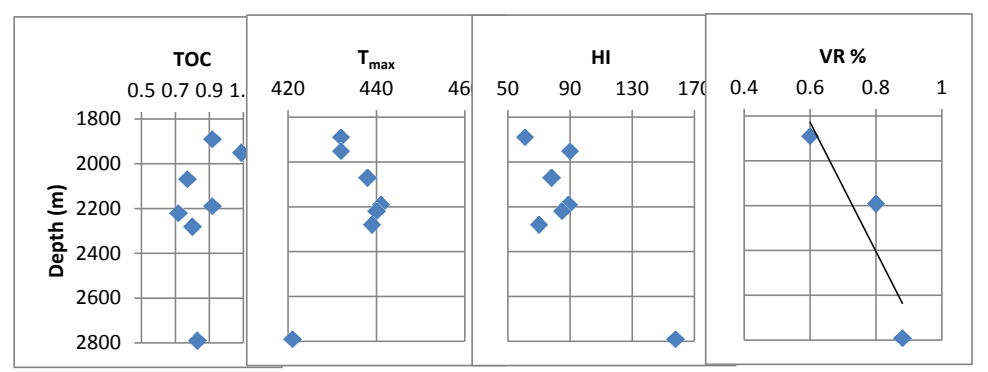

Figure 3: A plot of bulk geochemical and vitrinite reflectance data to determine source rock status of some strata penetrated by Kutchali- 1 well, Bornu Basin, Nigeria $\mathrm{A}=\mathrm{TOC}$ Vs Depth, $\mathrm{B}=\mathrm{Tmax}$ Vs depth, $\mathrm{C}=\mathrm{HI}$ vs Depth and C=VR\% vs Depth.

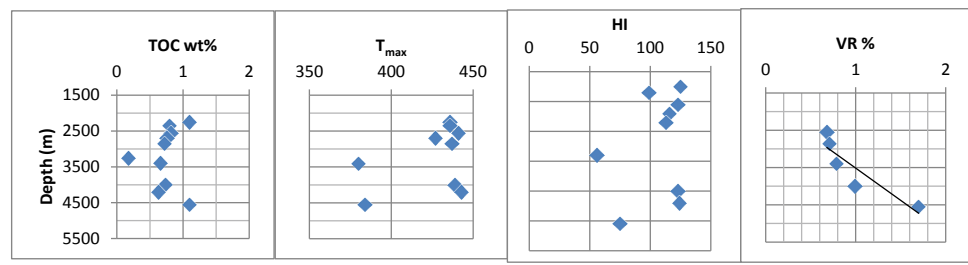

Figure 4: A plot of bulk geochemical and vitrinite reflectance data to determine source rock status of some strata penetrated by Herwa - 1 well, Bornu Basin, Nigeria.

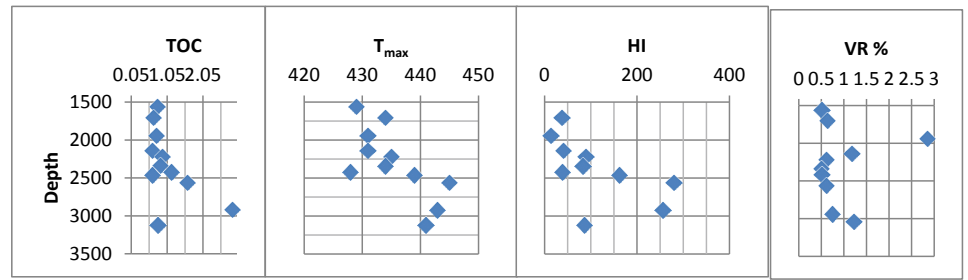

Figure 5: A plot of bulk geochemical and vitrinite reflectance data to determine source rock status of some strata penetrated by Faltu - 1 well, Bornu Basin, Nigeria. 
Citation: Ola PS, Adekoya JA, Olabode SO (2017) Source Rock Evaluation in The Lake Chad Area of the Bornu Basin, Nigeria. J Pet Environ Biotechnol 8: 346. doi: 10.4172/2157-7463.1000346

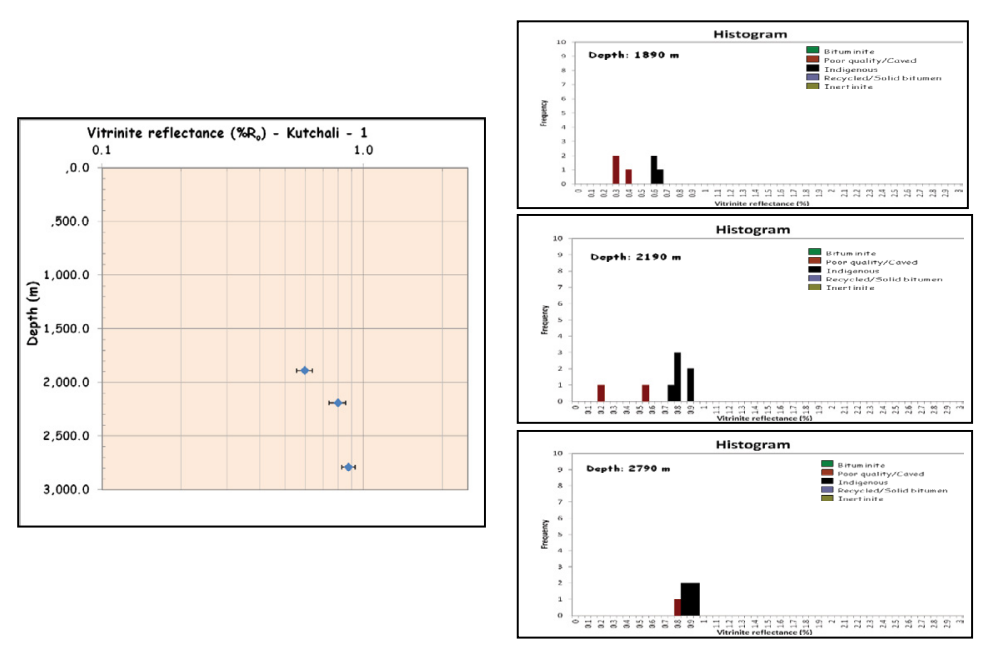

Figure 6: Whole rock vitrinite reflectance results for Kutchali-1. A. Depth plot of vitrinite reflectance, B. Histogram plots for the organic matter particles and vitrinite reflectance values obtained at different depths in the well.
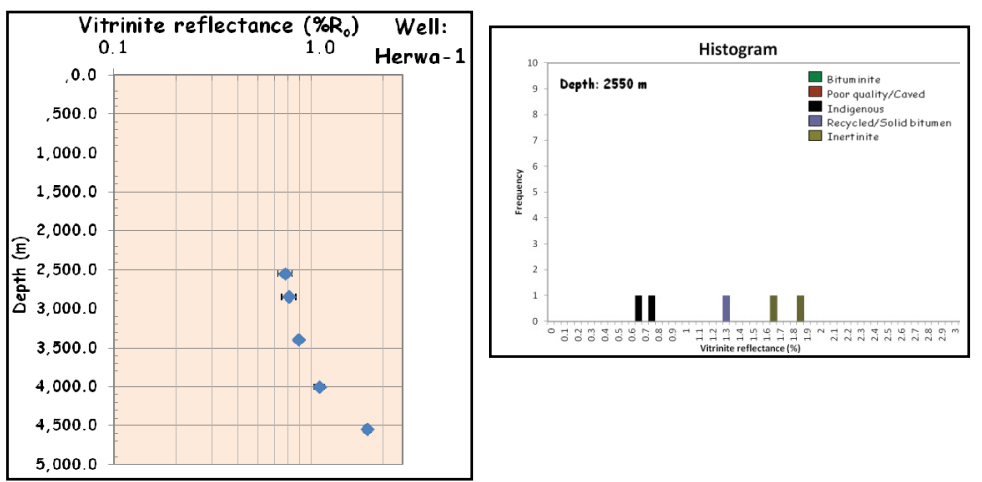

Figure 7: Vitrinite reflectance plots for Herwa- 1 well.

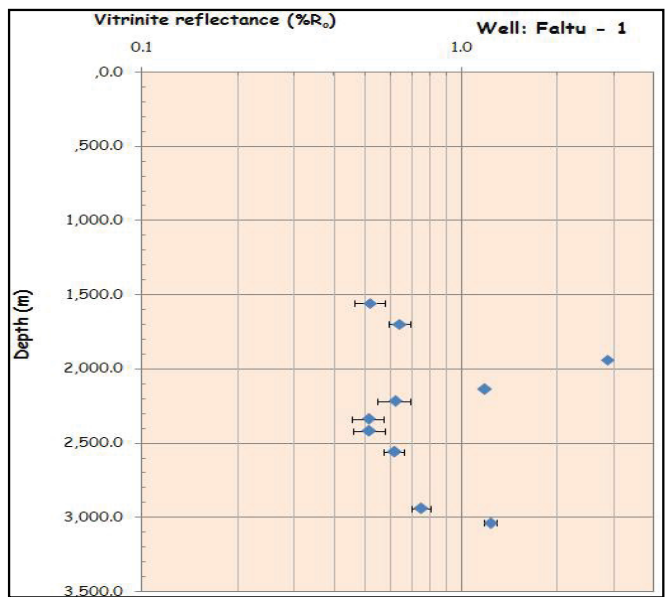

Figure 8: Vitrinite reflectance values for Faltu- 1 well.

and $2790 \mathrm{~m}$ were analysed in Kutchali-1 well (Figure 6). These samples were composed of powdered siltstone, carbonate grains and mudstone that had low organic matter content. Many particles were small and of poor quality. The most commonly occurring particle type was inertinite while a few particles appeared to be charred. Vitrinite was present in trace to low quantities and differentiation of primary from recycled vitrinite was often difficult. Only a few particles embedded in rock fragments were unequivocally deemed to be primary and used for this determination. There was no appreciable matrix bitumen stain while in a few samples the stain was light. Under blue light excitation, very low liptinite content was revealed. There were few algal cysts, which occasionally occurred as primary component that fluoresced yellow. However, one excellent trilete spore fluoresced light orange to mid orange with low intensity. Caved particles and some potentially drilling materials introduced as artifacts were present in all the sample. The vitrinite reflectance (VR) values obtained for the three samples were $0.60 \%$ Ro, $0.80 \%$ Ro and $0.88 \%$ Ro (Figure 6 ). Thermal maturation in the different samples from the various depths was assessed as early to peak oil window mature and late peak oil window mature (Table 3).

Herwa-1: Five ditch cutting samples selected at the following depths: $2550 \mathrm{~m}, 2850 \mathrm{~m}, 3400 \mathrm{~m}, 4000 \mathrm{~m}$ and $4550 \mathrm{~m}$, were subjected to vitrinite reflectance study. The samples were composed of mudstone and siltstone with moderate organic matter content dominated mostly by recycled particles of vitrinite, inertinite and coaly contaminants (Table 4) (Figure 7). Primary vitrinite was present at a relatively low quantity and was at most times difficult to distinguish from recycled organic matter. The VR obtained from the study were $0.68 \%$ Ro, $0.71 \%$ Ro, $0.79 \%$ Ro, $0.99 \%$ Ro and $1.70 \%$ Ro varying from the shallowest to the deepest level. Mineral matrix was lightly stained with bitumen. 
One tenuispore and orange spore fluoresced light orange with low to moderate intensity in a few samples while in other samples there was no convincing organic matter that shows flourescence. Some specimens in the samples exhibited artifacts of tiny pollen grains that showed flourescence. In others, trace spores fluoresced mid to dark orange with weak intensity. Hematite was present in some samples. Thermal maturation of the samples was considered to be at least peak oil window, late oil window and wet gas/condensate zone mature. The vitrinite reflectance values increase downhole (Figure 4d).

Faltu-1: In Faltu-1 well, ten ditch cutting samples were selected for vitrinite reflectance evaluation. They were picked at the following depths: $1560 \mathrm{~m}, 1700 \mathrm{~m}, 1940 \mathrm{~m}, 2140 \mathrm{~m}, 2220 \mathrm{~m}, 2340 \mathrm{~m}, 2420 \mathrm{~m}$, $2560 \mathrm{~m}, 2940 \mathrm{~m}$ and $3040 \mathrm{~m}$. The samples were made up of mudstone, silstone and shale with low to moderate organic matter content. They were dominated by inertinite and recycled vitrinite with subordinate contribution from primary vitrinite (Figure 8). Primary vitrinite was present as very small lenses and stringers that are high reflecting and poor to fair in quality often with degraded surfaces. There was abundance of phytoclasts that appear coal-like. Bituminite was occasionally present in few samples while liptinite was present in low amounts. Spore and trace spores fluoresced yellow-orange and light orange with moderate intensity, respectively. Hematite was fairly common and mineral matrix had light bitumen staining. The VR values attained for the sampled depths were $0.52 \%$ Ro, $0.64 \%$ Ro, $2.85 \%$ Ro, $1.18 \%$ Ro, $0.62 \%$ Ro,

\begin{tabular}{|c|c|c|c|c|}
\hline $\begin{array}{c}\text { Depth } \\
(\mathbf{m})\end{array}$ & Vitrinite reflectance (\% Ro) & $\begin{array}{c}\text { Standard } \\
\text { deviation }\end{array}$ & Count & $\begin{array}{c}\text { Confidence } \\
\mathbf{( 9 5 \% )}\end{array}$ \\
\hline 2550 & 0.68 & 0.05 & 2 & 0.48 \\
\hline 2850 & 0.71 & 0.06 & 3 & 0.14 \\
\hline 3400 & 0.79 & 0.03 & 4 & 0.05 \\
\hline 4000 & 0.99 & 0.05 & 4 & 0.09 \\
\hline 4550 & 1.7 & 0.06 & 2 & 0.56 \\
\hline
\end{tabular}

Table 3: Vitrinite reflectance result.

\begin{tabular}{|c|c|c|c|c|}
\hline $\begin{array}{c}\text { Depth/Sample } \\
\text { number }(\mathbf{m})\end{array}$ & $\begin{array}{c}\text { Vitrinite } \\
\text { reflectance (\%Ro) }\end{array}$ & $\begin{array}{c}\text { Standard } \\
\text { deviation }\end{array}$ & Count & $\begin{array}{c}\text { Confidence } \\
\mathbf{( 9 5 \% )}\end{array}$ \\
\hline 1560 & 0.52 & 0.06 & 6 & 0.06 \\
\hline 1700 & 0.64 & 0.05 & 6 & 0.05 \\
\hline 1940 & 2.85 & 0 & 1 & 0 \\
\hline 2140 & 1.18 & 0 & 2 & 0.03 \\
\hline 2220 & 0.62 & 0.07 & 6 & 0.08 \\
\hline 2340 & 0.51 & 0.06 & 11 & 0.04 \\
\hline 2420 & 0.52 & 0.06 & 11 & 0.04 \\
\hline 2560 & 0.62 & 0.04 & 13 & 0.03 \\
\hline 2940 & 0.75 & 0.05 & 13 & 0.03 \\
\hline 3040 & 1.23 & 0.06 & 11 & 0.04 \\
\hline & & & & \\
\hline
\end{tabular}

Table 4: Vitrinite reflectance plots for Herwa-1 well.
0.51\%Ro, $0.52 \%$ Ro, $0.62 \%$ Ro, $0.75 \%$ Ro and $1.23 \%$ Ro from the upper to the lower depths. These data indicate that the thermal maturation of the samples is dry gas zone, moderate to early oil window mature, late oil window and wet gas/condensate zone mature. The VR values exhibit irregularities with increasing depth.

\section{Source rock potential}

The level of maturity of the tested sections of the three wells derived from a plot of $\mathrm{HI}$ against $\mathrm{T}_{\mathrm{Max}}$ is displayed in Figure 9. To examine all lines of evidence based on available data, the kerogen potential and van Krevelen diagrams were plotted (Figure 10). Figure 9 reveals that the samples from the three wells fall between immature and mature (oil window) zone. While most Kutchali and Herwa samples plotted close to the margin of mature oil window zone with the immature zone, the Faltu samples concentrate largely in the mature zone.

As revealed by the van Krevelen diagram in Figure 10 the source rock for the Kutchali samples is Type II but very close to type III margin whereas the kerogen potential diagram $\left(\mathrm{S}_{2}\right.$ vs TOC) indicates type III kerogen which is gas prone. Herwa samples reveal type III kerogen indicating gas prone source rock like its Kutchali samples whereas those of Faltu show that they contain type II/III kerogen capable of generating both oil and gas.

\section{Discussion}

\section{Source rock evaluation in each of the three wells}

In this section, emphasis shall be laid on depth of sampling in each well in the Bornu Basin.

Kutchali well: Within the section studied in Kutchali well, the TOC is far above the $0.5 \mathrm{wt} \%$ threshold for hydrocarbon generation [25]. All the TOC values vary between $0.7 \mathrm{wt} \%$ and $1.1 \mathrm{wt} \%$ (Figure 4 ) (Table 1), indicating a fair source-rock generative potential (Figure 10). Recent data on TOC values from some Kutchali samples published by Alalade [8] also support a fair to very good source rock potential based on the obtained TOC values that range from 0.64-2.0 wt\%. However, these values are still less than those recorded in the neighbouring oil producing Termit Basin with TOC ranging from 1-30 wt $\%$ with averages of 2-3 wt\% [20].

The organic matter type in a source rock dictates the nature of hydrocarbon products. To know this important parameter, the following indicators are commonly used: van Krevelen plot, kerogen potential diagram and HI values. van Krevelen plot of samples from Kutchali-1 (Figure 10a) suggests type II kerogen with only one sample at the boundary of type III/II; However, the kerogen potential diagram (Figure 10b) indicates a gas prone type III kerogen.
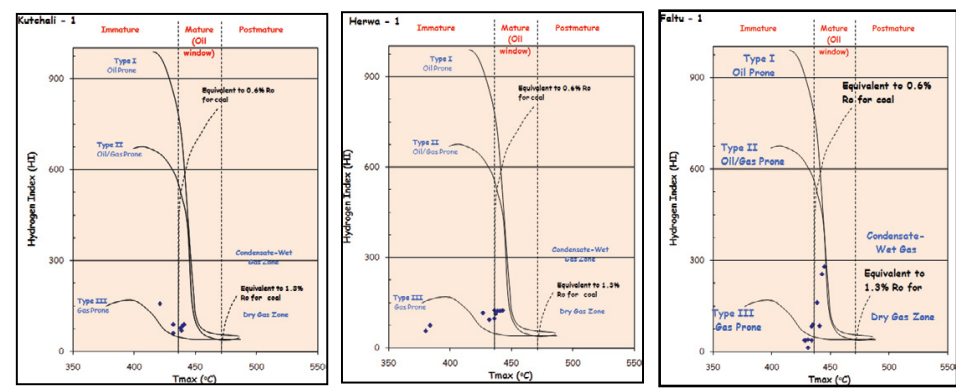

Figure 9: Plots showing type of kerogen and their level of maturation in three wells from the Chadian sector of the Bornu Basin, Nigeria. 

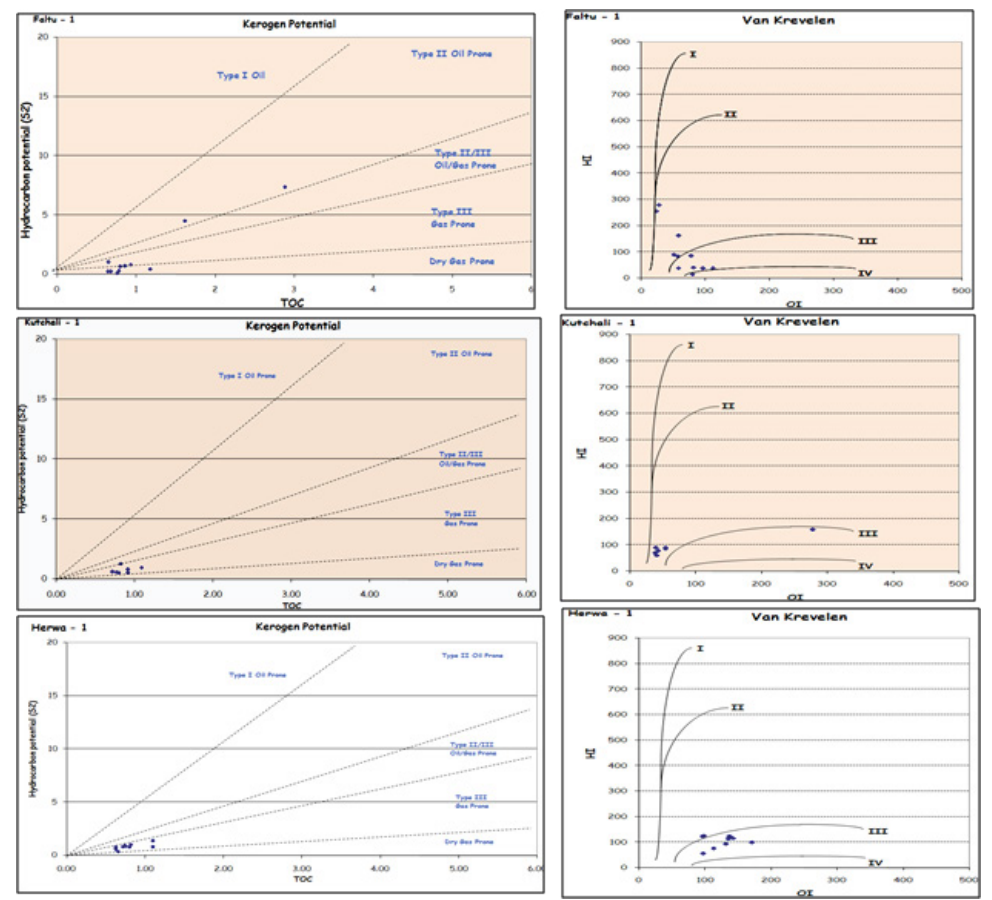

Figure 10: Plots showing hydrocarbon generation potential plots(A) (modified after Ghoria) and Van Krevelen diagrams (B)for three wells: Faltu- 1, Kutchali- 1 and Mbeji- 1 in the Lake chad area of the Bornu Basin.

The HI values obtained from the well dominantly range between 61 and 90 with only one sample reaching 158 . According to McCarthy [26], HI value of between 50 and 200 will lead to the generation of gas, which suggests that all the samples tested in Kutchali-1 are capable of generating gas. The maturity level of the organic matter as determined by the HI vs $\mathrm{T}_{\max }$ plot (Figure 9) and VR values (Figure 6) falls within the mature oil window although a few samples are immature, several authors recommend $435^{\circ} \mathrm{C} \mathrm{T}_{\max }$ as marking the onset of hydrocarbon generation, but $\mathrm{McCarthy}$ [26] put it at $440^{\circ} \mathrm{C}$ for type III kerogen. If the Tmax threshold value of $440^{\circ} \mathrm{C}$ is accepted for type III kerogen, then only Kutchali samples from depths below $2000 \mathrm{~m}$ (Figure 3b) which fall within the oil window (Figure 9) can generate gas.

Herwa-1 well: The organic matter richness of the sediments in Herwa-1 were determined using TOC values. The TOC values of the tested section of the well vary from 0.6 to $1.1 \mathrm{wt} \%$ (Table 1 ) implying that the sediments are sufficiently rich in organic matter for hydrocarbon generation. According to Peters (1986) the TOC values of between 0.5 and $1.0 \mathrm{wt} \%$ indicate a fair source-rock generative potential and from 1.0 to $2,0 \mathrm{wt} \%$ reflect a good generative potential.

All the samples analysed except two in Herwa-1 well have HI values greater than $100 \mathrm{mgHC} / \mathrm{gTOC}$ but not more than $150 \mathrm{mgHC} / \mathrm{gTOC}$ (Table 1), which, according to Peters [25], suggest a gas prone organic matter. Similarly, the kerogen potential diagram (Figure 10) also shows the plot of the samples in type III kerogen gas prone zone. However, the HI vs $\mathrm{T}_{\max }$ and the Krevelen plots suggest that the organic matter in the source rock facies is composed mainly of Type II/III (oil/gas prone) kerogen (Figures 9a and 10a). This shows that the source for the organic matter contents is predominantly from the terrestrial environment. Figure $9 \mathrm{~b}$ also reveals that most samples are oil window mature while a few are immature.

Thermal maturity level of the organic matter suggests that two of the samples having lower $\mathrm{T}_{\max }$ at deeper levels (Figure 4) might have suffered cooling attributable to uplift/exhumation as shown by the plot of $\mathrm{T}_{\text {max }}$ against depth (Figure 4).

Faltu-1 well: The results derived from the bulk geochemical analysis of samples from Faltu-1 well are displayed in Figure 5. TOC values derived from Faltu-1 well suggest that the well penetrated several organic rich beds (Table 2) (Figure 5a). All the values range from $0.64-2.88 \mathrm{wt} \%$ which are well above the $0.5 \mathrm{wt} \%$ threshold for $\mathrm{HC}$ generation. Organic rich facies of good source rock generative potential (TOC $>1.0$ wt\%, Peters [25]) even occur at depth of about $3000 \mathrm{~m}$, which is probably below the Fika Shale in the stratigraphic succession penetrated by the Faltu-1 well. Two samples from the well at depths of $2560 \mathrm{~m}$ and $2920 \mathrm{~m}$ have HI values of 280 and $256 \mathrm{mgHC} / \mathrm{gTOC}$, respectively (Table 1) with corresponding $\mathrm{T}_{\max }$ values of above $435^{\circ} \mathrm{C}$. This suggests that the sections contain types II/III and II kerogen which has genetic potential for generating both oil and gas. Both the Krevelen and kerogen potential plots (Figure 10) also confirm the Faltu kerogen to be type II (oil prone) and type III (gas prone). The thermal maturity level of the Faltu kerogen (Figure 9) indicates the type II kerogen is mature within the oil window and is oil/gas prone while the type III kerogen is immature. Therefore, based on the three parameters of TOC, $\mathrm{T}_{\max }$ and $\mathrm{HI}$ defined by Peters [25] and their variation with depth (Figure 5), several potential gas source intervals and two potential oil source intervals can be distinguished in Faltu-1 well. It can be reasonably inferred from Figure 5 that the potential oil source intervals probably lie between $2500 \mathrm{~m}$ and $3000 \mathrm{~m}$ depth in the well.

\section{Organic matter (kerogen) type and hydrocarbon generation potential}

The close relationship between organic matter and the type of hydrocarbon it can generate is well documented [25-28]. A plot of HI versus OI (van Krevelen diagrams) and $\mathrm{S}_{2}$ vs TOC used in this study show that most of the examined samples in the three wells consist of type III kerogen, which are capable of generating gas [27]. However, 
two samples in Faltu- 1 well recoding HI above 200 and type II kerogen have genetic potential for oil (Figure 10). One sample falls very close to the margin of Type II/III kerogen (Figure 10b). This sample is also capable of generating oil and gas.

\section{Source rock evaluation on a stratigraphic basis and in relation to other African basins}

The stratigraphic subdivision used in this study is based on Olabode [7]. Of the three wells (Kutchali -1, Herwa-1 and Faltu-1) studied in the Lake Chad area, all the samples identified as Bima Formation (Table 1) are mature $\left(\mathrm{T}_{\max }>435^{\circ} \mathrm{C}\right)$, except for one sample in Herwa-1 at a depth of $4550 \mathrm{~m}$ where the $\mathrm{T}_{\text {max }}$ is $384^{\circ} \mathrm{C}$. Similarly, Yolde Formation (Table 1) is considered mature (within the oil window) in all the wells. But the sample analysed in Faltu- 1 well in this formation at a depth of $2420 \mathrm{~m}$ is immature ( $\mathrm{T}_{\max }$ is $428 \mathrm{C}$ ) (Table 1). Samples were obtained from Gongila Formation in two wells (Faltu-1, (2340 m) and Kutchali-1 $(2790 \mathrm{~m})$ ). The formation is thermally mature in Faltu- 1 while it is immature in Kutchali-1 ( $\mathrm{T}_{\max }$ is $\left.421 \mathrm{C}\right)$. Majority of the samples analysed from the three wells in the Lake Chad area of the basin are from Fika Formation. This formation is thermally mature or very close to being mature in most of the wells having $\mathrm{T}_{\text {max }}$ values $>430^{\circ} \mathrm{C}$. In Herwa- 1 well low $\mathrm{T}_{\max }$ values $\left(380^{\circ} \mathrm{C}\right)$ was recorded for the same formation at depths 3400 $\mathrm{m}$. even though higher $\mathrm{T}_{\max }$ values were obtained at shallower depths (Table 1). Such a decrease in $\mathrm{T}_{\max }$ at deeper depths as observed in Bima and Fika Formations suggests cooling

Petroleum generation potential of any strata is directly related to its volume, organic richness and thermal maturity [26,27]. This study is concerned only with about the organic richness and maturity. Organic richness is a function of the amount and type of the organic matter in the sediments. In the three wells studied, samples of Gombe Formation, which are mainly reworked sediments deposited after the Santonian squeeze in the basin are predominantly sandstone and marl. Similarly, the Tertiary succession in the area of study consists of clay and sand. The implication of this is that, apart from the issue of type and maturity of organic matter, the Campano-Maastrichtian and Tertiary sediments of the study area in the Bornu Basin lack sufficient organic matter that could generate hydrocarbon and so were excluded from geochemical studies. This is in contrast to other oil producing rifts basins of WCARS such as the close by the Termit Basin that contains Cretaceous, as well as Tertiary lacustrine and marine source rocks and the Interior Sudan Basins where sediments of over $5,486 \mathrm{~m}$ with inter-bedded organic rich shale are recorded in the Tertiary [20,29]. In the complex rift systems of East Niger, both the Cretaceous marine shales and Oligocene lacustrine shales serve as source rocks [30].

\section{Organic matter maturation, tectonism and oil generation window}

In all the wells studied, the $\mathrm{T}_{\max }$ values do not show any consistent variation with depth while the VR values tend to display increase with depth in Kutchali and Herwa but are irregular in Faltu (Figures 3-5). However, a close study of the $T_{\max }$ variation with depth reveals noteworthy decreases at some levels. For example, in Kutchali there appears to be a decrease in $\mathrm{T}_{\max }$ from $440^{\circ} \mathrm{C}$ at a depth of $2220 \mathrm{~m}$ down to $421^{\circ} \mathrm{C}$ at $2800 \mathrm{~m}$ depth (Table 1) (Figure 3) but the Herwa $\mathrm{T}_{\max }$ plot shows 3 irregular decreases at $2600 \mathrm{~m}, 3450 \mathrm{~m}$ and $4500 \mathrm{~m}$ depths (Figure 4). The irregularities displayed by the Faltu $T_{\max }$ plot (Figure 5) reveal 2 subtle increasing and decreasing trends each. The first decreasing trend involves a decrease from $\mathrm{T}_{\text {max }}$ of $435^{\circ} \mathrm{C}$ at $2220 \mathrm{~m}$ depth to $428 \mathrm{C}$ at $2420 \mathrm{~m}$ depth and the second from $445^{\circ} \mathrm{C}$ at $2560 \mathrm{~m}$ to $441^{\circ} \mathrm{C}$ at $3120 \mathrm{~m}$. The $\mathrm{T}_{\max }$ decreases or irregular distribution with depth in the wells suggest cooling which can be occasioned by several geological factors including uplift leading to unconformities, faults, changes in geothermal gradients and contamination from migrated oils and bitumen [25,31]. According to Sahagian [32] a back-stripping study of the Chad Basin and Benue Trough suggests a better affinity between the Benue Trough and the Bornu Basin than between the Chad Basin and the Bornu Basin. The subsidence of the Benue Trough is dominated by early cretaceous rifting and rapid fault-bounded subsidence. $\mathrm{He}$ also observed that the post-faulting thermal subsidence history was interrupted by compressional folding in the Late Cretaceous, which correlates with the Santonian squeeze of Genik [20]. The Late cretaceous folding must have caused uplift resulting in the cooling suggested by the irregular $\mathrm{T}_{\max }$ history of the study area because the deposition of the studied sections predated the Santonian squeeze [24].

The "onset of oil generation window" delineated in this work probably occurs below $2000 \mathrm{~m}$ depth as suggested for Kutchali well. This is in agreement with the findings of Thomas [33] who estimated the threshold of the "oil window" in the Bornu Basin to be at a depth of $2000 \mathrm{~m}$ which correlates somewhat with the Genik's [20] suggestion of 2500-4000 m "oil window" in the rift basins of the West African Rift Subsystem that includes the Bornu Basin. A shallower "oil window" of $1522 \mathrm{~m}$ has been recommended by Nwankwo and Ekine [34] on the basis of geothermal gradient studies of the Bornu Basin. Such a "shallow oil window" will lie below the intra-Maastrichtian unconformity in the wells studied.

\section{Conclusion}

1. The conventional source rock evaluation tools using TOC and Rock-Eval pyrolysis of selected source rock intervals of the Cretaceous succession in the Lake Chad area presumably containing the thickest sediments in the Bornu Basin indicates a generally fair to moderately good amount of organic matter with TOC in the range of $0.63-2.88$ wt $\%$.

2. HI vs $\mathrm{T}_{\max }$ plots, supported by van Krevelen and $\mathrm{S}_{2}$ vs TOC plots, to determine the kerogen types and their maturity show that the dispersed organic matter in the source rock facies is composed mainly of Type III gas prone kerogen with subordinate Type II/III (oil/ gas prone) kerogen. This shows that the source for the organic matter contents is predominantly derived from terrestrial environment.

3. The variation of Tmax and VR with depth reveals irregular decreases or subtle decreasing trends that are suggestive of cooling in the basin's thermal history probably as a result of uplift and erosion. The uplift could have been caused by epeirogenic movement or by folding related to the Santonian squeeze of Genik [1].

4. A careful study of some bulk geochemical parameters (TOC, Tmax and HI) of the three study wells (Kutchali-1, Herwa-1 and Faltu-1) has revealed that the succession penetrated by the Faltu well contains several potential gas source intervals and two potential oil source intervals with the latter probably lying between $2500 \mathrm{~m}$ and 3000 m depth.

5. The onset of "oil generating window" probably occurs in parts of the Lake Chad area (the study area) below $2000 \mathrm{~m}$ depth based on the assumption of McCarthy [26] that type III kerogen can only become mature if subjected to Tmax of $440^{\circ} \mathrm{C}$.

6. Tertiary sequences in the study area, unlike those of the neighbouring rift basins (e.g. Termit Basin), are predominantly clay, marl and sandstone that are deficient in organic matter for hydrocarbon generation. 
Citation: Ola PS, Adekoya JA, Olabode SO (2017) Source Rock Evaluation in The Lake Chad Area of the Bornu Basin, Nigeria. J Pet Environ Biotechnol 8: 346. doi: 10.4172/2157-7463.1000346

\section{Acknowledgement}

This work is an excerpt from the report submitted to PTDF, Nigeria following the completion of the 2010 PTDF Research Competition. The authors are gratefu to Prof. R.W. Brown and Dr. K. Dobson of the University of Glasgow, UK for facilitating the geochemical analysis and the anonymous reviewers of the journa for their valuable suggestions that have led to the improvement of the initial draft of the paper.

\section{References}

1. Genik GJ (1992) Regional framework, structural and petroleum aspects of rift basins in Niger, Chad and Central African Republic (C.A.R.). Tectonophysics 213: 169-185.

2. Olugbemiro RO, Ligouis B, Abaa SI (1997) The Cretaceous series in the Chad Basin, NE Nigeria source rock potential and thermal maturity. J Pet Geo 20: $51-58$

3. Obaje NG, Wehner H, Scheeder G, Abubakar MB, Jauro A (2004a) Hydrocarbon prospectivity of Nigeria's inland basins: From the viewpoint of organic geochemistry and organic petrology. AAPG Bulletin 87: 325-353.

4. Obaje NG, Wehner H, Hamza H, Scheeder G (2004b) New geochemical data from the Nigerian sector of the Chad Basin: Implications on hydrocarbon prospectivity. J Afr Earth Sci 38: 477-487.

5. Moumouni A, Obaje NG, Nzegbuna Al, Chanda MS (2007) Bulk geochemical parameters and biomarker characteristics of organic matter in two wells (Gaibu-1 and Kasade-1) from Bornu Basin: Implications on hydrocarbon potentials. J Pet Geoscis Engineer 58: 275-282.

6. Adekoya JA, Ola PS, Olabode SO (2014) Possible bornu basin hydrocarbon habitat-A review. Int J Geosci5: 983-996.

7. Olabode SO, Adekoya JA, Ola PS (2015) Distribution of sedimentary formations in the Bornu Basin, Nigeria. Petrol Explor Develop 42: 674-682.

8. Alalade B (2016) Depositional environments of Late Cretaceous Gongila and Fika formations, Chad (Bornu) Basin, Northeast Nigeria. Marine Petroleum Geol 75: 100-116.

9. Browne SE, Fairhead JD (1983) Gravity study of the Central African rift system, a model of continental disruption, 1. The Ngaoundere and Abu Gabra rifts, Tectonophysics 94: 187-203.

10. Fairhead JD (1986) Geophysical controls on sedimentation within the African rift systems. Sedimentation in the African Rifts. Geol Sot London Spec Publ 25: 19-27.

11. Binks RM, Fairhead JD (1992) A plate tectonic framework for the evolution of the Cretaceous rift basins in West and Central Africa. In: Ziegler PA (ed) Geodynamics of Rifting, vol. 2, Case History studies on Rifts: North and South America, Africa-Arabia. Tectonophysics 213: 141-151.

12. Raeburn C, Jones B (1934) The Chad basin geology and water supply Nigeria Geol. Survey Bull.

13. Cratchley CR (1960) Geophysical Survey of the South-Western part of Chad basin. Unpub. Paper C.C.T.T. Conference Geology: Kaduna.

14. Carter JD, Barber W, Tait EA (1963) The Geology of parts of Adamawa, Bauchi and Borno provinces in NorthEastern Nigeria. Geol Surv Nigeria Bull 30:1-108.
15. Burke KC (1976) The Chad basin: An active intra-continental basin Tectonophysics 36: 197-206.

16. Ayoola EO, Amechi M, Chukwe R (1981) Nigeria's newer petroleum Exploration provinces: Benue, Chad Sokoto Basin. NMGS Conference.

17. Avbovbo AA, Ayoola EO, Osahon GA (1986) Depositional and structural styles in the Chad Basin of Northeastern Nigeria. AAPG Bull. 70: 1787-1798.

18. Fairhead JD, Binks RM (1991) Differential opening of the Central and South Atlantic Oceans and the opening of the Central African rift system. Tectonophysics 187: 191- 203.

19. Guiraud R, Maurin I (1992) Early cretaceous rifts of Western and Central Africa: An overview. In: Ziegler PA (ed), Geodynamics of Rifting, Volume II. Case history studies on rifts: North and South America and Africa. Tectonophysics 213: 153-168.

20. Genik GJ (1993) Petroleum geology of cretaceous-tertiary rift basins in Niger Chad and Central African Republic. AAPG Bull 77: 1405-1434.

21. Whiteman AJ (1982) South Atlantic Continental drift and the Benue trough Tectonophysics 6: 301-310.

22. Popoff M (1988) Du Gondwana a l'Atlantique sud, les connexions du fosse de la Benoue avec les bassins du nordest Bresilien jusq a l'louverture du Golfe du Guinee au Cretace inferieur. J African Earth Sci 7: 409 - 431

23. Okosun EA (1995) Review of the geology of Bornu Basin. J Min Geo 31: 113 122

24. Adekoya JA, Ola PS, Olabode SO (2015) Petroleum potential of the nigerian sector of the chad basin using integration of apatite fission track analysis Conventional methods and basin modelling. A report submitted to PTDF after the completion of the 2010 PTDF Research competition.

25. Peters KE (1986) Guidelines for evaluating petroleum source rock using programmed pyrolysis. AAPG Bull. 70: 318-329.

26. McCarthy K, Rojas K, Niemann M, Palmowski D, Peters K, et al. (2011) Basic Petroleum geochemistry for Source Rock Evaluation. Oilfield Review.

27. Hunt J (1986) Petroleum Geochemistry and Geology. W. H. Freeman and Company, New York, USA. p. 143.

28. Tissot BP, Welte DH (1984) Petroleum formation and occurrence. (2nd edn) Springer-Verlag, Berlin.

29. Schull J (1988) Rift basins of interior Sudan: Petroleum exploration and discovery. AAPG 72: 1128-1142.

30. Zanguina M, Bruneton A, Gonnard R (1998) An introduction to the petroleum potential of Niger. J Pet Geol 21: 83-103.

31. Peters KE, Cassa MR (1994) Applied source rock geochemistry. In: Magoon LB. and Dow GW (eds.), The petroleum system from source to trap. AAPG Memoir 60: 93-120.

32. Sahagian DL (1993) Structural evolution of African basins: stratigraphic synthesis. Basin Research 5: 41-54.

33. Thomas D (1996) Nigeria-5 Benue trough and the mid-African Rift System. Oi Gas J. pp.102-169.

34. Nwankwo CN, Ekine AS (2009) Geothermal gradients in the Chad Basin Nigeria, from bottom hole temperature logs. Int J Phys Sci 4: 777-783. 